\title{
11 \\ Publificación de la gestión: la intervención temporal de Sociedades Cooperativas en la legislación vigente
}

\author{
María Burzaco Samper \\ Profesora de Derecho Administrativo \\ Universidad Pontificia de Comillas
}

\begin{abstract}
Sumario: I. Introducción.-II La intervención temporal como modalidad de intervención de empresas. A. Concepto. B. La reserva de ley contenida en el artículo 128.2 CE y su alcance.--III. La intervención temporal en la legislación sobre sociedades cooperativas. A. La causa que legitima la intervención temporal. 1. Presupuestos habilitantes. 2. La relevancia del interés público subyacente. B. El acuerdo de intervención: procedimiento para su adopción. 1. Modos de iniciación. 2. Tramitación. 3. Resolución. C. Las medidas de intervención. 1. Tipología. a) Intervención-presidencia; b) Intervención-aprobación; c) Intervención-sustitución. 2. Naturaleza jurídica de la intervención temporal.-IV. Los derechos constitucionales afectados. Consecuencias en los principios de aplicación. A. Los derechos constitucionales afectados por la intervención. 1. Apuntes preliminares. 2. Intervención temporal y derecho a la libertad de empresa. B. Los principios en la adopción y aplicación de la intervención temporal. 1. El principio de proporcionalidad. 2. El carácter temporal y su indefinición.- $\mathrm{V}$. Conclusiones.
\end{abstract}

\section{Introducción}

La intervención temporal de las sociedades cooperativas por parte de la Administración Pública constituye una figura extrema de intervención pública no siempre contemplada en la normativa existente en la materia1.

1 Suelen citarse como antecedentes los arts. 52 y 118 del Reglamento para la aplicación de la Ley de Cooperativas de 1931 (Gaceta de Madrid núm. 294, de 21 de octubre de 1931), si bien circunscribían la intervención gubernativa a dos supuestos muy singulares:

a) El artículo 52 permitía el nombramiento de «uno o varios comisarios encargados de ultimar lo más rápidamente posible las operaciones de liquidación», «si trans- 
Así, se recogió específicamente en el Reglamento de Cooperación de $1971^{2}$ (artículo 93) y, con posterioridad, en el Reglamento de $1978^{3}$ (artículo 136). Tras la aparición de la legislación cooperativa postconstitucional, la primera norma que incorpora esta previsión es la Ley de Cooperativas de la Comunidad Valenciana de $1985^{4}$ (artículo 106, posteriormente modificado por Ley 3/1995, de 2 de marzo5, que pasó a ser el artículo 109 del Texto Refundido de la Ley de Cooperativas de la Comunidad Valenciana $\left.{ }^{6}\right)$, que, sin embargo, se ha visto suprimida en la ley actualmente vigente ${ }^{7}$. Un caso similar se produce en la legislación estatal que prevé la intervención temporal en la Ley de $1987^{8}$ (artículo 152), para hacerla desaparecer en la actual Ley de 1999. En cuanto al resto de las leyes cooperativas, únicamente prevén esta modalidad interventora la leyes de Aragón ${ }^{10}$ (artículo 96), Extre-

currido un mes desde el acuerdo de disolución no hubieren comenzado las operaciones de liquidación, cualquiera que sea el motivo, o se interrumpieren por más de ese tiempo después de comenzadas, o se llevaren con lentitud maliciosa». Dicha medida se adoptaba por el Ministerio a petición de un número de socios no inferior a la quinta parte del total o a propuesta de la Subcomisión especial del Consejo de Trabajo.

b) El artículo 118 preveía la intervención de Cooperativas escolares «en caso de perturbación estudiantil» y «al solo efecto de evitar que sirvan de instrumento para la perturbación o que ésta cause daño a los intereses de la Cooperativa», correspondiendo la decisión al Ministerio del que dependiera el centro de enseñanza.

2 Decreto 2.396/1971, de 13 de agosto, por el que se aprueba el Reglamento de Cooperación (BOE núm. 242, de 9 de octubre de 1971)

3 Real Decreto 2.710/1978, de 16 de noviembre, por el que se aprueba el Reglamento de aplicación a las Sociedades Cooperativas reguladas por la Ley 52/1974, de 19 de diciembre (BOE núm. 275, de 17 de noviembre de 1978)

4 Ley 11/1985, de 25 de octubre, de Cooperativas de la Comunidad Valenciana (DOGV núm. 300, de 31 de octubre de 1985; BOE núm. 54, de 4 de marzo de 1986)

5 Ley 3/1995, de 2 de marzo, de modificación de la Ley 11/1985, de Cooperativas de la Comunidad Valenciana (DOGV núm. 2467, de 10 de marzo de 1995; BOE núm. 101, de 28 de abril de 1995)

6 Decreto Legislativo 1/1998, de 23 de junio, del Gobierno Valenciano, por el que se aprueba el Texto Refundido de la Ley de Cooperativas de la Comunidad Valenciana (DOGV núm. 3275, de 30 de junio de 1998)

7 Ley 8/2003, de 24 de marzo, de Cooperativas de la Comunidad Valenciana (DOGV núm. 4.468, de 27 de marzo de 2003; BOE núm. 87, de 11 abril de 2003). En adelante, LCCV.

8 Ley 3/1987, de 2 de abril, General de Cooperativas (BOE núm. 84, de 8 de abril de 1987). En adelante, LGC.

9 Ley 27/1999, de 16 de julio, de Cooperativas (BOE núm. 170, de 17 de julio de 1999)

10 Ley 9/1998, de 22 de diciembre, de Cooperativas de Aragón (BOA núm. 151, de 31 de diciembre de 1998; BOE núm. 23, de 27 de enero de 1999); En adelante, LCA. 
madura $^{11}$ (artículo 181), Galicia12 (artículo 140), y País Vasco ${ }^{13}$ (artículo 142), no haciéndolo las demás.

Un análisis de los preceptos mencionados nos muestra que la intervención temporal presenta dificultades de diverso signo residenciadas en su propia configuración y alcance, aspectos que trataremos de poner de manifiesto a lo largo de este trabajo.

\section{La Intervención Temporal como modalidad de Intervención de Empresas}

\section{A. Concepto}

GADEA $^{14}$ ha definido la intervención temporal de cooperativas como «la facultad que la Ley atribuye a la Administración para actuar en el ámbito interno de una cooperativa; es decir, es la capacidad que la Ley le otorga para introducirse directamente en sus órganos sociales, mediatizando bajo su control la actividad de los mismos en un espacio de tiempo determinado».

Estamos, pues, ante la traslación al ámbito cooperativo de una técnica de injerencia pública conocida en el Derecho Administrativo económico ${ }^{15}$ como «intervención de empresas» que, siguiendo a GAMERO,

11 Ley 2/1998, de 26 de marzo, de Sociedades Cooperativas de Extremadura (DOE 49/1998, de 2 de mayo; BOE núm. 128, de 29 mayo de 1998). En adelante, LCE.

12 Ley 5/1998, de 18 de diciembre, de Cooperativas de Galicia (DOG núm. 251, de 30 de diciembre de 1998; BOE núm. 72, de 25 marzo de 1999). En adelante, LCG.

13 Ley 4/1993, de 24 de junio, de Cooperativas de Euskadi (BOPV núm. 135, de 19 de julio de 1993). En adelante, LCPV. La ley derogada por ésta (Ley 1/1982, de 11 de febrero) no contenía un precepto similar al actual artículo 142.

14 Gadea Soler, Enrique, Derecho de las cooperativas. Análisis de la Ley 4/1993, de 24 de junio, de cooperativas del País Vasco, Universidad de Deusto, Bilbao, 1999, pág. 330.

15 Esta figura constituye, sin duda, una manifestación de la intervención pública en la economía que, como es sobradamente conocido, ha vivido una expansión inusitada que Roso divide en tres grandes fases: un primer estadio caracterizado por la sustitución del «laissez-faire, laissez paiser» por la planificación indicativa y la idea de Administración como prestadora de servicios públicos, hecho éste que conllevó una ampliación decisiva de las fórmulas clásicas de actuación administrativa (policía, fomento y servicio público). Un segundo paso estaría marcado por el «principio de la iniciativa pública en la actividad económica en concurrencia - e igualdad-con la privada»; siendo la tercera y última de tales fases, la aparición de un nuevo orden jurídico llamado a cumplir una doble función: por un lado, como «instrumento para la constitución de un nuevo orden económico»; por otro, «como instrumento para su mantenimien- 
puede conceptuarse como «una potestad administrativa y extraordinaria, en cuya virtud, por razones de interés general previamente definidas en una norma con rango de ley, la Administración asume, directa o indirectamente, y con carácter temporal, las facultades propias de los órganos de una empresa determinada, incidiendo sobre su gestión ordinaria o sobre su liquidación, con respeto de los derechos patrimoniales de los sujetos afectados» ${ }^{16}$.

Se trata, en suma, de una situación activa en manos de la Administración consistente, en esencia, en una publificación de la gestión ${ }^{17}$ llevada a cabo a través de mecanismos que suponen una intromisión de variado orden en los órganos de la cooperativa, pero sin que afecten formalmente a la titularidad de la misma.

Un tipo de injerencia que tiene un carácter excepcional desde un doble plano: por una parte, porque sus presupuestos legitimadores remiten a la existencia de circunstancias de especial gravedad que justifican esta actuación pública dirigida a la salvaguarda del interés general. Y excepcional, por otro lado, en cuanto, dado el carácter de las medidas interventoras, éstas constituyen una quiebra temporal de la

to». Roso, Angel, «El Derecho económico como categoría sistemática», en VVAA, Estudios de Derecho Mercantil en homenaje al profesor Antonio Polo, Editorial Revista de Derecho Privado/Edersa, Madrid, 1981, págs. 983-984.

Sobre la conversión del Derecho de la Economía de Derecho de guerra en Derecho de paz y la idea del Estado como «conductor de la Economía» que no sólo «fija las líneas generales de su política económica», sino también "se proyecta sobre esferas concretas de la actividad económica y productiva», véase también PoLo, Antonio, «El nuevo Derecho de la Economía. Su aparición, concepto y relaciones con el Derecho Mercantil», Revista de Derecho Mercantil, vol. I, núm. 3, mayo-junio 1946, págs. 379381 y 402.

16 Gamero CasAdo, Eduardo, La intervención de empresas. Régimen jurídico administrativo, Marcial Pons, Madrid, 1996, págs. 18 y 143. Esta magnífica obra es, sin duda, la investigación más profunda sobre la intervención de empresas y nos remitiremos a ella en múltiples ocasiones. Dividida en dos partes, la primera de carácter dogmático y la segunda centrada en el análisis de la legislación sectorial, en ésta última se dedica un epígrafe a la intervención de cooperativas, si bien debemos advertir que, dado el momento en el que se publica, únicamente alude al régimen previsto en el antiguo artículo 152 de la LGC de 1987, norma ya derogada. Es evidente que la irrupción de la normativa autonómica sobre sociedades cooperativas ha complicado el panorama de esta figura y exige un estudio de las particularidades que cada Comunidad Autónoma aporta.

17 Hernando Delgado, Justo, «La intervención pública de empresas privadas», en WAA, Homenaje a José Antonio García-Trevijano Fos, Colegio Universitario de Estudios Financieros-Instituto de Estudios de Administración Local, Madrid, 1982, pág. 713. 
autonomía cooperativa y una limitación máxima del derecho a la libertad de empresa reconocido en el artículo 38 CE.

\section{B. La reserva de ley contenida en el artículo 128.2 CE y su alcance}

De acuerdo con el artículo 128.2 CE, «mediante ley se podrá (...) acordar la intervención de empresas cuando así lo exigiere el interés general».

Aun cuando nadie pone en entredicho que el empleo de la fórmula «mediante ley» constituye una reserva de ley ${ }^{18}$, la controversia se ha suscitado en relación con el alcance de la misma. Dicho de otro modo, la cuestión se centra en dilucidar si la CE exige que cada intervención de empresas venga precedida de una ley ad hoc, y por tanto singularizada ${ }^{19}$, o, por el contrario, cabe una previsión legal general

18 Es conocido que la Constitución española emplea a lo largo de su articulado locuciones muy variadas que no en todos los casos se han interpretado como auténticas reservas materiales de ley. Una enumeración exhaustiva de la variedad de fórmulas a las que nos referimos puede encontrarse en SANTAMARÍA PASTOR, Juan Alfonso, Principios de Derecho Administrativo, vol. I, Editorial Centro de Estudios Ramón Areces, Ma-

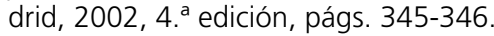

En otro orden de cosas, Justo HeRnANDo subraya que esta reserva es coherente con el criterio constitucional en relación con cualquier restricción a los «dos postulados básicos que en ella se reconocen: la libertad y la propiedad». En este sentido y pese a que es común la opinión de que la intervención no afecta a la propiedad de la empresa, aquélla podría constituir "un primer paso que hace posible ese traspaso», de modo que la reserva de ley podría resultar un instrumento preventivo tendente a la protección del mencionado derecho. Hernando Delgado, Justo, op. cit., págs. 716 y 717.

19 La existencia de leyes singulares o "de caso único» ha sido fuente de recelos que el TC trató de disipar en su conocida Sentencia 166/1986, de 19 de diciembre. En ella se afirmaba que «el dogma de la generalidad de la Ley no es obstáculo insalvable que impida al legislador dictar, con valor de Ley, preceptos específicos para supuestos únicos o sujetos concretos», si bien «no quiere (...) decir que las Leyes singulares sean totalmente equiparables a las Leyes generales en el sentido de que constituyan ejercicio normal de la potestad legislativa, sino que se configuran como ejercicio excepcional de esta potestad, subordinada a rigurosos límites (...) en el marco de nuestro Derecho Constitucional» (FJ Décimo). Tales límites se manifiestan en un triple plano:

a) Respeto al principio de igualdad (artículo 14 CE), de suerte que «la Ley singular sólo será compatible con [éste] cuando la singularidad de la situación resulte inmediatamente de los hechos, de manera que el supuesto de la norma venga dado por ellos y sólo quepa al legislador establecer las consecuencias jurídicas necesarias para alcanzar el fin que se propone. El control de constitucionalidad opera así en un doble plano, para excluir la creación arbitraria de supuestos de hecho, que sólo resultarían singulares en razón de esa arbitrariedad y para asegurar la razonabilidad, en función del fin propuesto, de las medidas adoptadas» [FJ Undécimo, a)]. 
que habilite después la actuación administrativa interventora mediante procedimientos y actos administrativos aplicativos de aquélla.

Téngase en cuenta que si, según hemos afirmado, la intervención temporal de cooperativas no es sino una modalidad de intervención de empresas, las leyes cooperativas que introducen la figura como una técnica más y otorgando la competencia a la Administración Pública para su puesta en práctica mediante actos de aplicación, podrían plantear dudas sobre su constitucionalidad en este punto.

Lo cierto es que las opiniones doctrinales acerca de la instrumentación formal de la intervención han sido muy dispares: así, hay autores que entienden necesaria una ley singular para cada medida interventora lo que, de algún modo, encuentra apoyo en la interpretación que se ha llevado a cabo de la locución constitucional — «mediante ley»- en relación con otros instrumentos a los que acompaña en el precitado artículo $128.2 \mathrm{CE}^{20}$.

No obstante, puede afirmarse que la opinión mayoritaria aboga por interpretar la norma de manera más flexible: desde este punto de vista, es perfectamente respetuosa con la Constitución la ley general que prevea el instrumento de intervención administrativa estableciendo el o los supuestos de hecho que dan pie a la misma y las medidas

b) «(...) la adopción de Leyes singulares debe estar circunscrita a aquellos casos excepcionales que, por su extraordinaria trascendencia y complejidad, no son remediables por los instrumentos normales de que dispone la Administración, constreñida a actuar con sujeción al principio de legalidad, ni por los instrumentos normativos ordinarios, haciéndose por ello necesario que el legislador intervenga singularmente, al objeto exclusivo de arbitrar solución adecuada, a una situación singular» [FJ Undécimo b)].

c) «Los derechos fundamentales no consienten, por su propia naturaleza, Leyes singulares que tengan el específico objeto de condicionar o impedir su ejercicio; dichos derechos son materia reservada a Leyes generales y reducto inmune a medidas legislativas singulares» [FJ Undécimo C)].

STC (Pleno) 166/1986, de 19 de diciembre; rec. 704/1984; Ponente: DíAz EIMIL, Eugenio; BOE 3/1987, de 3 enero; Referencia Jurisprudencia El Derecho Editores (en adelante, EDJ) 1986/166.

20 Nos referimos en concreto a las «reservas al sector público de recursos o servicios esenciales»; reservas que deben hacerse singularmente, lo que, dicho de otro modo, implica la aprobación de una ley para cada recurso o para cada sector que se pretende sustraer del régimen de concurrencia competitiva mediante la reserva. Se pronuncia en estos términos Roso, Ángel, «Actividad económica pública y actividad económica privada en la Constitución Española», Revista de Derecho Mercantil, núm. 169/170, julio-diciembre 1983, pág 340. 
concretas en que aquélla consiste ${ }^{21}$. Las razones en apoyo de esta tesis son muy heterogéneas y, en algunos casos, discutibles ${ }^{22}$.

A nuestro juicio, y siguiendo nuevamente a GAMERO, entendemos que ambas fórmulas tienen cabida: la ley singular, con los límites que para este instrumento ha diseñado el TC23; y la ley general, como modalidad idónea para dar «el mejor acomodo posible a dos necesidades constitucionales contrapuestas: por una parte, el respeto de los derechos individuales, y por otro, la eficacia de la actuación administrativa» ${ }^{24}$.

Por lo demás, el TC en una de sus controvertidas Sentencias sobre el caso RUMASA, vino a corroborar esta tesis en los siguientes términos:

«La expresión «mediante ley» que utiliza el mencionado precepto [en alusión al artículo 128.2 CE], además de ser comprensiva de Leyes generales que disciplinan con carácter general la intervención, permite la Ley singularizada de intervención que mediando una situación de extraordinaria y urgente necesidad y, claro es, un interés general legitimador de la medida, está abierta al Decreto-ley, por cuanto la mención a la Ley no es identificable en exclusividad con el de Ley en sentido formal» (STC 111/1983, de 2 de diciembre; FJ Décimo $)^{25}$.

Atendiendo a lo expuesto, debemos concluir que, en efecto, la existencia de una previsión general contenida en las diversas leyes cooperativas se ajusta, en su vertiente formal, a la CE.

Obsérvese que no hemos puesto en entredicho la propia competencia autonómica para, en ejercicio de su potestad legislativa, aprobar normas que contengan la posibilidad de intervención temporal regulando los supuestos de hecho y las medidas concretas de intervención. En este sentido, conviene poner de manifiesto que la intervención en cuanto instrumento no constituye «materia compe-

21 Hernando Delgado, Justo, op. cit., págs. 718-719.

22 Una enunciación muy amplia de los argumentos a favor y en contra, puede encontrarse en GAMERO CASADO, Eduardo, op. cit., págs. 117-119, en nota al pie núm. 214.

23 Nos remitimos a la doctrina expuesta en la STC 166/1986 (Fundamentos Jurídicos Décimo y Undécimo) y que ya ha sido transcrita en la nota al pie núm. 19.

24 Gamero CASADO, Eduardo, op. cit., pág. 124.

25 STC (Pleno) 111/1983, de 2 de diciembre; rec. 116/1983; Ponente: ArozAMEnA SIERRA, Jerónimo; BOE 298/1983, de 14 diciembre; EDJ 1983/111. 
tencial»26; mas al contrario, se liga a las diversos ámbitos sectoriales siguiendo su devenir. Esto explica, por ejemplo, que la intervención de sociedades cooperativas (en general, y sin referencia a la actividad que desarrollen) pueda normarse mediante leyes autonómicas en sus distintos extremos; y que, sin embargo, la intervención temporal de las cooperativas de crédito se encuentre mediatizada por las reglas de intervención establecidas por el Estado para las entidades de este sector ${ }^{27}$.

26 Puede resultar desconcertante el hecho de que determinados Estatutos de Autonomía recogieran entre sus competencias el desarrollo legislativo y la ejecución de las bases en materia de intervención de empresas (artículo 11.2 Estatuto de Autonomía del País Vasco; artículo 10.1 EA Cataluña; artículo 28 EA Galicia; artículo 15 EA Andalucía; artículo 32.1 EA Comunidad Valenciana; artículo 57 Ley Orgánica de Reintegración y Amejoramiento del Régimen Foral de Navarra). Sin embargo, y siguiendo la jurisprudencia constitucional, los instrumentos y técnicas de los que las distintas Administraciones Públicas se sirven en cada ámbito competencial no pueden ser entendidas como títulos atribuidos a una u otra Administración o, en su caso, asignados a más de una de ellas de forma compartida o concurrente porque esto llevaría a disfunciones carentes de sentido. Así las cosas, la regulación de una determinada medida, técnica, instrumento, etc. ha de separarse de lo que es estrictamente su empleo (el caso paradigmático tal vez lo constituya la expropiación forzosa, cuya regulación es exclusivamente estatal, si bien ello no empece a que su ejercicio se lleve a cabo por las distintas Administraciones Públicas territoriales).

Volviendo a la intervención de empresas, cabría un análisis de los distintos títulos competenciales que, de modo más o menos directo, se ven implicados (algo que excede, obviamente, del objeto de este estudio). Puede admitirse incluso la oportunidad de una ley estatal que ofrezca una regulación general de la misma con base en los distintos apartados del artículo 149.1 que pueden traerse a colación, pero más allá de tales consideraciones no cabe excluir el ejercicio de esta potestad de intervención por parte de las CCAA en los sectores económicos en los que éstas tienen asumidas competencias exclusivas.

Sobre este punto, véase GAMERO CASADO, Eduardo, op. cit., págs. 129-140.

27 Ley 26/1988, de 29 de julio de Disciplina e Intervención de las Entidades de Crédito (BOE 182/1988, de 30 de julio).

Esta Ley fue objeto de recurso de inconstitucionalidad resuelto por STC 96/1996 en cuyo FJ Undécimo puede leerse: «El pfo. b) del mismo artículo 42,7, por su parte, declara básicos íntegramente los preceptos del Tít. III de la Ley, relativo a las medidas de intervención y de sustitución de los órganos de administración o dirección de las entidades de crédito. Por consiguiente, el Estado no solamente determina las normas correspondientes, sino que se reserva la ejecución de estas medidas, en los supuestos en que "una entidad de crédito se encuentre en una situación de excepcional gravedad que ponga en peligro la efectividad de sus recursos propios o su estabilidad, liquidez o solvencia» (artículo 31.1 LDIEC).

Basta con examinar el supuesto que desencadena la intervención del Banco de España para apreciar el carácter básico de la regulación, y que la atribución de facultades puramente ejecutivas en estos supuestos excepcionales se encuentra justificada, como 


\section{La intervención temporal en la legislación sobre sociedades cooperativas}

\section{A. La Causa que legitima la Intervención Temporal \\ 1. Presupuestos habilitantes}

Por lo general, el supuesto de hecho que permite acordar la intervención temporal se define con base en una serie de conceptos jurídicos indeterminados que, por su propio carácter, encierran importantes dificultades interpretativas. Pero además, y a pesar de ciertos elementos comunes, algunas de las regulaciones se configuran de un modo excesivamente abierto que, aun sin constituir por sí mismas atribución de discrecionalidad administrativa ${ }^{28}$, permiten aventurar la complejidad del eventual control judicial posterior.

Tanto la LCA como la LCE exigen la existencia de «circunstancias que pongan en peligro» intereses de los socios o de terceros ${ }^{29}$; peligro

hemos tenido ocasión de declarar en la sentencia sobre las Cajas de Ahorro de Cataluña y Galicia (STC 48/88, f. j. 26). Esta conclusión, como es obvio, en nada altera las que alcanzamos en aquella ocasión acerca de la validez de las medidas de intervención que pueden adoptar las autoridades autonómicas, con arreglo a su propia legislación, siempre que sea compatible con la eventual intervención estatal.» [STC (Pleno) 96/1996, de 30 de mayo; rec. 1.710/1988; Ponente: Rodríguez BereiJo, Alvaro; BOE 150/1996, de 21 junio; EDJ 1996/2.469]

Por otra parte, el propio TC ha afirmado que las facultades interventoras señaladas en dicha Ley 26/1988 y que se atribuyen al Banco de España (arts. 31 y 32) se incluyen «en la competencia estatal en materia de crédito y coordinación de la planificación económica» $\mathrm{y}$, por tanto, dentro del ámbito competencial estatal. [FJ Tercero de STC (Pleno) 134/1992, de 5 de octubre; rec. 661/1985; Ponente: Cruz ViLlalón, Pedro; BOE 260/1992, de 29 octubre; EDJ 1992/9.637]

28 Conforme ha tenido ocasión de recordar el Tribunal Supremo, los conceptos jurídicos indeterminados «aunque en su apreciación se introduzca con frecuencia un porcentaje de discrecionalidad, en razón del halo de dificultad que caracteriza el espacio de incertidumbre que media entre las zonas de certeza positiva y negativa (sentencias del TS de 31 de diciembre 1988, 8 de noviembre de 1990 y 12 de abril de 1996)» no desvirtúa la naturaleza reglada de una determinada potestad [FJ Séptimo, STS (Sala 3. ${ }^{a}$, sección 5. ${ }^{\text {a) }}$, de 21 de noviembre de 2000; rec. 6.437/1995; Ponente: Sanz Bayón, Juan Manuel; EDJ 2000/42.971]. En todo caso, conviene no confundir este hecho con el carácter discrecional de la potestad en sí misma considerada. En este sentido debemos hacer hincapié en que esta potestad de intervención está configurada como potestad discrecional, si bien dicha discrecionalidad no procede de la apertura e indeterminación de los supuestos de hecho habilitantes, sino del carácter potestativo con el que se contempla su ejercicio. Sobre este punto abundaremos posteriormente.

29 La ley extremeña incorpora la mención a «asociados», hecho éste que no altera en sustancia la definición del presupuesto habilitante. 
que, sólo en la primera de las citadas, se exige sea «grave». Independientemente del relevante matiz que tal adjetivación incorpora, las locuciones empleadas en ambos casos apuntan simplemente a «circunstancias», pudiendo por tanto quedar incluidas no sólo aquéllas de origen interno a la propia entidad cooperativa, como otras que, siendo de procedencia externa, influyen en aquélla determinando la puesta en peligro de los intereses mencionados. Conviene hacer notar que este enunciado es prácticamente copia del contenido en el artículo 152 de la hoy derogada LGC de 1987, que ya fue duramente criticado por varios autores ${ }^{30}$.

El legislador gallego ha optado por una fórmula en apariencia similar, aunque a nuestro entender más intrincada y técnicamente menos correcta. En el artículo 140.1 LCG podemos leer: «cuando como consecuencia del conocimiento de irregularidades concurran circunstancias que pongan en peligro la propia cooperativa o los intereses de los socios o de terceros (...)». Las preguntas inevitables que surgen tras la lectura de este artículo derivan de la inclusión de una primera parte en la que las circunstancias habilitantes se ligan al "conocimiento de irregularidades». Este hecho parece entroncar la intervención con una previa inspección y con la posible apertura de expediente sancionador por posibles infracciones administrativas. Aunque, como veremos después, la intervención temporal se conforma de manera independiente al ejercicio de la potestad sancionadora, lo cierto es que la dicción del precepto reduce las «circunstancias» a razones de índole interna, trabadas a irregularidades cometidas en el seno de la cooperativa y, sean o no éstas, conductas tipificadas como infracción.

Esa vinculación es aún mayor en la ley vasca: «cuando como consecuencia de irregularidades en una cooperativa se den circunstancias que aconsejen la adopción de medidas urgentes para evitar que se lesionen gravemente intereses de los socios o de terceros (...)». En este caso, la forma en la que se ha redactado el precepto conduce a afirmar que el presupuesto para decidir la intervención temporal está compuesto por dos requisitos acumulativos: a) Las circunstancias que aconsejen la adopción de medidas urgentes deben ser consecuencia de irregularidades; y b) Dichas medidas tratan de evitar la lesión grave

30 Paz Canalejo en su comentario a este artículo en VVAA (dir. Sánchez Calero, Fernando y Albaladejo, Manuel), Comentarios al Código de Comercio y Legislación mercantil especial, Tomo XX, vol. 3, Editorial Revista de Derecho Privado/Edersa, Madrid, 1994, pág. 903; GAMERO CASADO, Eduardo, op. cit., pág. 524. 
de intereses de los socios o de terceros ${ }^{31}$. Resulta, pues, evidente que estamos ante un supuesto de hecho más restringido que los anteriores: de un lado, porque, al igual que en el caso gallego, se une a la presencia de irregularidades que, aunque no necesariamente susceptibles de constituir infracciones administrativas, remiten a causas exclusivamente internas a la propia cooperativa; de otro, porque se exige que la lesión a los intereses tutelados que se pretende evitar, sea grave.

En todo caso, y como hace Paz CANalejo, debe recalcarse que la intervención temporal sólo puede ir dirigida hacia sociedades cooperativas en su "sentido técnico-jurídico estricto», quedando excluida la posibilidad de intervención gubernativa de todas aquellas fórmulas de naturaleza asociativa y no societaria ${ }^{32}$.

\section{La relevancia del interés general subyacente}

De acuerdo con el artículo 128.2 CE, la intervención de empresas podrá acordarse "cuando así lo exigiere el interés general», mención que LÓPEZ RODÓ consideró «ambigua y peligrosa» porque «el concepto de interés general se presta a múltiples interpretaciones» ${ }^{33}$. Sin despreciar las complicaciones derivadas de la necesaria concreción del término «interés general» —auténtica piedra angular del Derecho Administrativo-, es inobjetable que la legitimidad de la intervención temporal de sociedades cooperativas pasa por perfilar el interés público que le sirve de soporte y que no siempre se muestra de forma clara en la letra de la ley.

Comúnmente la figura de la intervención de empresas se ha relacionado con situaciones de crisis económicas ${ }^{34}$, configurándose como

31 VVAA (dir. Paz Canalejo, Narciso), Glosa a la Ley de Cooperativas de Euskadi, Consejo Superior de Cooperativas de Euskadi, Vitoria-Gasteiz, 1999, pág. 505.

32 Paz Canalejo, en VVAa (dir. Sánchez Calero, Fernando y Albaladejo, Manuel), Comentarios al Código de Comercio,... op. cit , pág. 902.

33 López Rodó, Laureano, «El modelo económico de la Constitución», en VVAA, Administración y Constitución. Estudios en homenaje al profesor Mesa Moles, Servicio Central de Publicaciones de la Presidencia del Gobierno, Madrid, 1981, pág. 447.

34 En este sentido, García ECHEVARRía señala que «se plantea generalmente más un problema de saneamiento empresarial, en unos casos, y de reestructuración por reconversión, en otros». García EchevarRía, Santiago, «El orden económico en la Constitución», Libre Empresa, año II, núm. 8, septiembre-octubre 1978, pág. 39.

El propio TS participa de algún modo de esta inercia como lo refleja la Sentencia de 29 de marzo de 1996 en la que puede leerse: «(...) el artículo 128,2 de la Constitución 
un medio de salvamento de empresas, hecho que posiblemente encuentre explicación en sus orígenes históricos ${ }^{35}$. Sin embargo, y como señala OJeDA MARín ${ }^{36}$, los motivos de la intervención no deben circunscribirse a razones de esta índole.

La normativa cooperativa es buena muestra de ello. En efecto, tal y como hemos reseñado en el apartado anterior, los supuestos que permiten la adopción del acuerdo de intervención corresponden a situaciones en las que no necesariamente estamos ante eventuales dificultades económicas; en otras palabras, la intervención temporal de cooperativas presupone la existencia de circunstancias críticas, sean éstas económicas o de cualquier otro carácter.

Llegados a este punto, se exige un paso más dirigido a materializar el interés público en presencia. No se trata ya de verificar cuándo se da el supuesto de hecho, sino por qué se prevé dicho supuesto; cuál es, en suma, el interés público ${ }^{37}$ que la intervención pretende proteger y en el que ésta encuentra amparo. Un extremo que adquiere especial importancia si atendemos al carácter discrecional de esta potestad lo que determina que la mera verificación del supuesto de hecho no conlleva necesariamente el ejercicio de la misma. En síntesis, la idea sería: la concurrencia del supuesto habilitante presupone la existencia de un interés que se estima digno de protección, pero no siempre éste adquiere la suficiente relevancia pública para que la Administración decida ejercitar su potestad interventora.

Vayamos por partes:

a) Las sociedades cooperativas, en cuanto desarrollan actividades empresariales, entran en sectores económicos que son de trascendencia para el conjunto de la economía nacional y/o regio-

se refiere a una intervención de empresas por motivos económicos (...)» [FJ Segundo, STS (Sala Tercera, Sección 4. ${ }^{a}$ ) de 29 de marzo de 1996, rec. 7431/1994; Ponente: Baena del Alcázar, Mariano; EDJ 1996/3.288]

35 Sobre la formación histórica de la intervención de empresas y sus antecedentes más próximos, véase GAMERO CASADO, Eduardo, op. cit., págs. 26-48; HeRNANDo DelGADO, Justo, op. cit., págs. 714-715.

36 Ojeda Marín, Alfonso, "La intervención de empresas en el ordenamiento vigente (Sobre la incautación de Hytasa y su constitucionalidad)», Revista Española de Derecho Administrativo, núm. 57, enero-marzo 1988, pág. 75.

37 Bassols ha subrayado la importancia del interés público como «causa material» de la intervención de empresas. Bassols COMA, Martín, Constitución y sistema económico, Tecnos, Madrid, 1985, pág. 202. 
nal. Esta vertiente macroeconómica determina la necesidad de estabilidad, regularidad y corrección en su funcionamiento ${ }^{38}$ no sólo como fines en sí mismos, sino también en evitación de los riesgos que directa o indirectamente pudiera provocar su quiebra económica, la comisión de irregularidades, etc. para la economía considerada en su conjunto 39 .

b) En cumplimiento del artículo 129.2 CE, las CCAA con competencia en la materia han asumido como tarea de interés general la promoción, estímulo y desarrollo del cooperativismo elevándolo a categoría de principio general ${ }^{40}$. Sin negar que el sentido de estas previsiones tiende a dirigir la actividad administrativa hacia el fomento del cooperativismo, lo cierto es que

38 HeRnANDo destaca que «los ordenamientos sectoriales se refieren a la figura de la intervención de las empresas de sus propios ámbitos normativos como instrumentos para mantenerlas en la disciplina del sector o corregir y rectificar con la intervención pública sus deficiencias». Hernando Delgado, Justo, op. cit., pág. 721.

GADEA eleva a características de la intervención temporal sus fines de control y corrección, considerándola un medio «para frenar las irregularidades, corregirlas y evitar graves perjuicios». GADEA SOlER, Enrique, op. cit., pág. 332.

39 El sector crediticio es buen ejemplo de ello. La propia STC 96/1996 citada con anterioridad hace referencia a ello en su FJ Primero: "Con arreglo a estas ideas cardinales, la Ley 26/88 somete a las entidades de crédito a un régimen especial de supervisión administrativa, en general mucho más intenso que el de otros sectores económicos. Sus fines son paliar las carencias de información y de conocimientos del público y facilitar la confianza en dichas entidades; confianza que es considerada una condición imprescindible para el desarrollo y buen funcionamiento de las instituciones de crédito, esencial para el conjunto de la economía. Las piezas capitales de la ordenación son, básicamente, un conjunto de normas tendentes a facilitar a la autoridad supervisora una completa información sobre la situación y evolución de las entidades financieras, y otro conjunto dirigido a prevenir los riesgos de insolvencia o falta de liquidez de éstas».

Por lo demás, esta importancia del sector cooperativo para la economía regional se subraya en la Exposición de Motivos (en adelante, EM) de la LCA, que incorpora, a su vez, el concepto de relevancia social: «El modelo cooperativo tiene una importante función económica en la Comunidad Aragonesa, fundamentalmente como factor de progreso de las zonas rurales, ya que es creador de riqueza y empleo, determinando el mantenimiento de los modos de vida y cultura locales, al tiempo que constituye un tipo de sociedad de especial relevancia social que se caracteriza por la solidaridad y la participación de los socios en la toma de decisiones». De igual modo, en la EM de la LCG, cuando dice: "El análisis de la realidad de las cooperativas gallegas evidencia el peso de esta forma empresarial de organización y ordenación de los recursos y su destacada importancia en la estructura socioeconómica de Galicia».

40 Artículos 97 LCA; 164 LCE; 137 LCG; 137 LCPV. En cuanto al último de los artículos citados, es de destacar que se prevé que «Las entidades cooperativas que contribuyan a la promoción del interés general de Euskadi mediante el desarrollo de sus funciones serán reconocidas de utilidad pública por el Gobierno Vasco (...)». 
aquélla presenta cierto aspecto tuitivo que no puede soslayar$\mathrm{se}^{41}$. A nuestro entender, la existencia de tal principio impregna la intervención con un significado de protección del cooperativismo que no puede desgajarse de la misión de una Administración Pública que, de acuerdo con el artículo 103.1 CE, «sirve con objetividad a los intereses generales».

c) El amplio espectro de actividades que llevan a cabo las cooperativas y que encuentra reflejo en la variada tipología de sus clasificaciones ${ }^{42}$, determina lo que podríamos llamar «interés público sectorial». Este se configuraría como el interés general en conexión con los derechos y principios que le sirven de enlace con el ordenamiento constitucional. Así, por ejemplo, las cooperativas de enseñanza en relación con el derecho fundamental a la educación del artículo 27 CE ${ }^{43}$, las cooperativas de vivienda con el artículo 47 CE, las sanitarias con el artículo 43 $C E$, las de integración social con el artículo 49 CE, ... y todas ellas con arts. como el 40, 45, 50 CE, etc.

En este contexto los postulados del Estado Social y Democrático de Derecho vienen a convertirse en el punto de confluencia entre el cooperativismo y el concepto de interés público, porque siendo cierto que éste no puede apartarse de aquellos, también lo es que el cooperativismo constituye un cauce eficaz para hacerlos efectivos.

d) La lectura de los preceptos que contemplan la intervención temporal ofrece un fin inmediato aparentemente más reducido: la protección de los socios y de terceros. Sin embargo, hemos de poner de relieve que tal interés lo es por su reconducción a lo que los socios y terceros obtengan de la actividad cooperativa, lo que de algún modo nos coloca de nuevo en el que hemos denominado «interés público sectorial».

41 Divar ha hecho notar que las facultades administrativas de fiscalización se conforman como «contrapartida» del «interés preferente» que poseen las Cooperativas y que las coloca como beneficiarias de la actividad administrativa de fomento. DIVAR GarteizaurReCoA, Javier, Régimen jurídico de las Sociedades Cooperativas, Universidad de Deusto, Bilbao, 1987, pág. 75.

42 Título II, capítulo I LCA; Título I, capítulo XIII LCE; Título III, capítulo I LCG; Título II, capítulo I LCPV.

43 Por concretar más el ejemplo, la intervención temporal en una cooperativa de enseñanza podría ampararse en la necesidad de proteger este derecho fundamental a la educación de sus alumnos caso de que la situación de la cooperativa pudiera poner en riesgo la propia culminación de un curso académico. 


\section{B. El Acuerdo de Intervención: Procedimiento para su Adopción}

Los preceptos que regulan la intervención temporal dedican lacónicas referencias al procedimiento para la adopción del acuerdo de intervención. En ellas, y como no podía ser de otro modo, se especifican las autoridades competentes para dictar dicha resolución; sin embargo, sólo en algunos casos se alude a los modos de iniciación del procedimiento, limitándose las especificaciones relativas a la tramitación a los eventuales informes a recabar.

Conviene destacar, no obstante, que las normas del procedimiento administrativo común recogidas en la Ley 30/92, de 26 de noviembre de Régimen Jurídico de las Administraciones Públicas y del Procedimiento Administrativo Común (en adelante, LRJAP) actúan como derecho supletorio a los efectos de colmar las lagunas de esta legislación sectorial, y ello sin perjuicio de las especialidades procedimentales que hayan podido establecerse en sede autonómica ${ }^{44}$.

44 El artículo 2 LRJAP extiende el ámbito de aplicación de esta ley a las Administraciones de las CCAA. No obstante, ha de tenerse en cuenta que el TC ha interpretado que «aunque al Estado compete regular el procedimiento administrativo común (artículo 149.1.18 (E), ello no obsta a las especialidades derivadas de la organización propia de las Comunidades Autónomas, que pueden adaptar por ello las reglas comunes a sus necesidades e intereses peculiares respecto de los procedimientos especiales que aprueben en materia de su competencia» [FJ Vigésimo tercero letra I) de la STC (Pleno) 227/1988, de 29 de noviembre, rec. 824/1985; Ponente: Leguina Villa, Jesús; BOE 307/1988, de 23 de diciembre; EDJ 1988/543].

Son muchas las CCAA que han aprobado normas procedimentales de adaptación a la LRJAP referidas a su ámbito competencial, aunque por lo que interesa a nuestro trabajo citaremos exclusivamente las que siguen:

—Galicia: Ley 6/2001, de 29 de junio, de adecuación de la normativa de la Comunidad Autónoma de Galicia a la Ley 4/1999, de 13 de enero, de modificación de la Ley 30/1992, de 26 de noviembre, de régimen jurídico de las administraciones públicas y del procedimiento administrativo común. (BOE 178/2001, de 26 julio; DOG 135/2001, de 12 julio)

—Aragón: Ley 8/2001, de 31 de mayo, de adaptación de procedimientos a la regulación del silencio administrativo y los plazos de resolución y notificación (BOE 148/2001, de 21 junio; BOA 67/2001, de 8 junio)

-Extremadura: Decreto 98/2001, de 26 de junio, por el que se adaptan procedimientos de la Junta de Extremadura en aplicación de la Ley 30/1992, de 26 de noviembre, de Régimen Jurídico de las Administraciones Públicas y del Procedimiento Administrativo Común, y se publica su inventario (DOE 76/2001, de 3 julio). 


\section{MODOS DE INICIACIÓN}

Tanto la LCA como la LCPV aluden a que el procedimiento puede ser iniciado de oficio o a instancia de cualquier interesado ${ }^{45}$. Por el contrario las leyes extremeña y gallega silencian este punto, aunque a nuestro entender pueden admitirse igualmente ambas modalidades ${ }^{46}$ (artículo 68 LRJAP).

En relación con este aspecto, debe recordarse que estamos ante el manejo del concepto amplio de interesado propio del Derecho Administrativo que, como es sabido, extiende notablemente la legitimación para la participación en el procedimiento comparativamente a lo que es común en otras disciplinas ${ }^{47}$.

\section{TRAMITACIÓN}

Las especificidades procedimentales relativas a la tramitación apenas se contemplan. Los arts. 140.2 LCG y 142.2 y 3 LCPV establecen con carácter preceptivo la emisión de informe por parte de los corres-

45 Sólo el Reglamento de 1978 establecía ciertos límites en este sentido, por cuanto exigía que la petición fuera del Consejo Rector o de los Interventores de Cuentas; asimismo, caso de que lo instara un número de socios que representara el $10 \%$ del total o, en Cooperativas con menos de 500 miembros, el 20\% de dicho total (artículo 136. 2 Reglamento 1978).

Un caso peculiar lo constituye la LCCV de 1985 —actualmente derogada- que distinguía los modos de iniciación según las circunstancias concurrentes: así, la intervención podía ser solicitada por petición razonada de cualquier socio «en caso de graves irregularidades de una entidad cooperativa, que aconsejen medidas urgentes para evitar daños a terceros o a los socios», procediendo la iniciación de oficio cuando, en las mismas circunstancias, "las entidades hayan obtenido subvenciones y otras ayudas de los poderes públicos» (esta redacción se mantuvo tras la reforma operada por la ley 3/1995). Obsérvese la restricción en el ámbito subjetivo de la solicitud, que sólo podía realizarse por socios de la entidad.

46 Tenemos que hacer notar que en el caso de que se interpretara este silencio en el sentido de admitir únicamente una iniciación de oficio, ello no cerraría el paso de los posibles interesados en dicha iniciación, si bien éste se produciría de un modo más indirecto. Recuérdese que de conformidad con el artículo 69.1 LRJAP «los procedimientos se iniciarán de oficio por acuerdo del órgano competente, bien por propia iniciativa o como consecuencia de orden superior, a petición razonada de otros órganos o por denuncia».

La forma de iniciación del procedimiento puede tener consecuencias importantes a efectos de la resolución final, y más en concreto, ante la eventual producción del silencio administrativo, como veremos más adelante.

47 Artículo 31 LRJAP. 
pondientes Consejos de Cooperativas, señalándose a tal efecto un plazo de 10 y 15 días $^{48}$, respectivamente, teniéndose por evacuado transcurrido dicho plazo.

Desde nuestro punto de vista, hubiera sido deseable que las restantes leyes cooperativas que prevén la intervención temporal contuvieran igualmente la obligatoriedad de este informe. Dado el carácter extraordinario que aquélla posee, la resolución administrativa que pone fin al procedimiento debería adoptarse con las máximas cautelas; cautelas proyectadas en una doble dirección: en primer término, sobre la propia respuesta — positiva o negativa - a la intervención; en segundo lugar, y caso de que el juicio anterior fuera afirmativo, sobre la medida o medidas concretas a poner en práctica que deben estar presididas por una serie de principios que analizaremos al término de este estudio.

Por otro lado, no debe olvidarse que a través de los Consejos de Cooperativas se canaliza una modalidad de participación ${ }^{49}$ que podemos considerar entroncada en la cláusula del Estado Democrático y, en tal sentido, su presencia adquiere connotaciones que deben ser tenidas en cuenta.

48 PAZ CANALEjo ha criticado la cortedad de este plazo por considerarlo insuficiente para emitir un informe de estas características. Paz Canalejo, Narciso, en VVAA (dir. SÁnchez Calero, Fernando y Albaladejo, Manuel), Comentarios al Código de Comercio..., op. cit., pág. 907.

Debemos considerar, sin embargo, que estamos ante una duración que es la habitual en el ámbito de los procedimientos administrativos y que, por lo demás, es acorde con el propio plazo de duración del procedimiento, cuestión a la que aludiremos posteriormente.

49 Este carácter participativo de los Consejos de Cooperativas encuentra perfecto reflejo en su composición mixta que une a representantes de la Administración y de las cooperativas: artículo 136 LCG y artículo 4 Decreto 25/2001, de 18 de enero, por el que se regula la organización y funcionamiento del Consejo Gallego de Cooperativas (DOG 27/2001, de 7 febrero); artículo 145 LCPV y artículo 5 Decreto 213/1999, de 11 de mayo por el que se regula el Consejo Superior de Cooperativas de Euskadi (BOPV 106/1999, de 7 de junio); Disposición Adicional 4. ${ }^{a}$ LCA y artículo 4 Decreto 65/2003, de 8 de abril, del Gobierno de Aragón, por el que se regula el Consejo Aragonés del Cooperativismo (BOA 53/2003, de 5 mayo); artículo 186.2 LCE y artículo 4 Decreto 130/1998, de 17 de noviembre, por el que se aprueba el Reglamento de Organización y Funcionamiento del Consejo Superior del Cooperativismo de Extremadura, modificado por Decreto 246/2000, de 5 de diciembre (DOE 140/1998, de 5 diciembre y DOE 144/2000, de 12 diciembre, respectivamente) 
En todo caso, nada obsta para que el órgano encargado de dictar la resolución pueda recabar los informes que estime pertinentes ${ }^{50}$ incluyendo, cómo no, el del respectivo Consejo de Cooperativas.

Merece cierta consideración el carácter no vinculante del informe que, según hemos hecho constar, se tiene por evacuado si transcurrido el plazo para su emisión ésta no se ha producido. Sin negar que ésta pueda ser una fórmula habitual en la normativa administrativa y que en los casos de intervención temporal pueda verse justificada por la celeridad que exige — al menos aparentemente - la toma de la decisión, lo cierto es que puede interpretarse como una merma en las garantías de la entidad intervenida. Esta circunstancia es especialmente relevante en el caso gallego, cuyo artículo 140.1 LCG establece una presunción de que el informe no emitido, se tiene por realizado en sentido favorable.

En cualquier caso, las lacónicas referencias procedimentales deberán ser completadas con las que rigen el procedimiento administrativo general y, muy especialmente, las relativas al trámite de audiencia (artículo 84 LRJAP), cuya trascendencia en procedimientos de los que pueden derivarse actuaciones administrativas limitativas está fuera de cuestión ${ }^{51}$.

50 Conforme al artículo 82.1 LRJAP, «a efectos de la resolución del procedimiento, se solicitarán aquellos informes que sean preceptivos por disposiciones legales, y los que se juzguen necesarios para resolver, citándose el precepto que los exija o fundamentando, en su caso, la conveniencia de reclamarlos».

51 Sobre la importancia del trámite de audiencia en los procedimientos de intervención de empresas, Gamero CASADO, Eduardo, op. cit., págs. 259-265.

Habida cuenta de las consecuencias limitativas que comporta la intervención, este autor opina que estamos ante un trámite esencial, cuya omisión determinaría la nulidad de pleno derecho del acuerdo por subsunción en el artículo 62.1 e) LRJAP (actos "dictados prescindiendo total y absolutamente del procedimiento establecido (...)»). No obstante hemos de advertir que, aunque existe jurisprudencia en este sentido (si bien no referida específicamente a este mecanismo administrativo), la realidad demuestra que el análisis de cada caso no plantea una solución homogénea. En principio, la omisión del trámite de audiencia, en la medida en que sea generadora de indefensión, suele incluirse dentro de la regla general de la anulabilidad (artículo 63.2 LRJAP: "No obstante, el defecto de forma sólo determinará la anulabilidad cuando el acto carezca de los requisitos formales indispensables para alcanzar su fin o dé lugar a la indefensión de los interesados»). Por otra parte, para entenderse producida esta indefensión no basta la mera omisión de este trámite, sino que se atiende a que efectivamente aquélla se haya creado de suerte que si el interesado ha podido defender sus derechos o intereses haciendo uso de los diversos mecanismos impugnatorios, no suele estimarse la concurrencia del vicio señalado. 


\section{Resolución}

En su aspecto material la resolución administrativa que pone fin al procedimiento deberá señalar si procede o no la intervención y, en caso afirmativo, especificar qué medida o medidas concretas deberán ponerse en práctica.

Por otra parte, y en cuanto cualquier medida interventora de las previstas posee naturaleza ablatoria, se exige que la decisión esté motivada con expresión de las razones de hecho y de derecho que justifican la misma ${ }^{52}$ y que, ulteriormente, permitirán verificar el control judicial caso de una eventual impugnación por parte de la cooperativa destinataria del acto o de cualquier persona que vea afectados derechos o intereses legítimos.

Por lo demás, las diversas leyes se limitan a concretar qué órgano administrativo posee la competencia para dictar esta resolución bien atribuyéndosela a un único órgano (el Consejo de Gobierno autonómico en Aragón53; el Consejero competente en materia de trabajo en Galicia ${ }^{54}$ ), bien distribuyéndola en dos distintos según cuál sea la medida a adoptar (así, en Extremadura, el Director General de Trabajo de la Consejería de Presidencia y Trabajo o el Consejero de Presidencia y Trabajo55; de igual modo en el País Vasco, el Director de Economía Social o el Consejero de Trabajo y Seguridad Social ${ }^{56}$ ). En general, esta atribución es coherente con la asignación de las facultades de inspección ${ }^{57}$ y encuentra su lógica interna en el cumplimiento de las exigencias de eficacia en la actuación administrativa (artículo 103. 1 CE).

En otro orden de cosas, algunas de las normas advierten del carácter «ejecutivo» o «inmediatamente ejecutivo» del acuerdo. Como

52 Si bien ninguna de las regulaciones cita expresamente este requisito formal de la motivación, su exigencia resulta ineludible en cuanto la resolución constituye un acto que limita derechos subjetivos o intereses legítimos (artículo 54.1 a) LRJAP).

53 Artículo 96.1 LCA.

54 Artículo 140.1 y 2 LCG.

55 Artículo 181.2 LCE.

56142.3 LCPV.

57 Esta perspectiva de la intervención ligada a las autoridades administrativas competentes para la inspección, ha provocado cierta confusión en cuanto a la naturaleza que aquélla posee y que HERNANDO ha llegado a calificar de «intervención-sanción». Esta opinión, que no compartimos, se explica por la finalidad de «salvamento de empresas en crisis» a la que él vincula este mecanismo público y a la que no siempre se reduce la regulación sectorial, como ocurre en el caso de las cooperativas. HeRnANDo Delgado, Justo, op. cit., pág. 721. 
es sabido, la ejecutividad es característica propia de todo acto administrativo (artículo 56 LRJAP) y actúa con independencia de la interposición de los recursos que procedan en vía administrativa o jurisdiccional (artículo 111.1 LRJAP), sin perjuicio de la posible suspensión de la ejecución del acuerdo ${ }^{58}$.

Por lo que respecta al ámbito de la publicidad, sólo en algún caso se menciona la necesidad de publicación en el correspondiente Diario Oficial ${ }^{59}$, exigencia que, a nuestro juicio, debería haberse contemplado en todas las normas autonómicas por razones de seguridad jurídica.

En cuanto al plazo para dictar y notificar la resolución, sólo la ley aragonesa lo contempla expresamente especificando que su duración es de 30 días. Por su parte, cabe citar también el anexo del «Decreto 98/2001, de 26 de junio, por el que se adaptan procedimientos de la Junta de Extremadura en aplicación de la Ley 30/1992, de 26 de noviembre, de Régimen Jurídico de las Administraciones Públicas y del Procedimiento Administrativo Común, y se publica su inventario» en el que se concreta el plazo para la adopción de cada una de las medidas contempladas en el artículo 181.1 LCE y que cifra en todo caso en 3 meses.

Por el contrario, tanto la LCG como la LCPV omiten este dato lo que obliga a la aplicación del plazo supletorio de 3 meses señalado en el artículo 42.3 LRJAP, pudiéndose acordar la tramitación de urgencia conforme a lo señalado en el artículo 50 LRJAP60.

58 En lo concerniente a la suspensión en vía administrativa, el artículo 111.2 LRJAP señala que puede acordarse bien de oficio, bien a instancia del recurrente por el órgano encargado de la resolución del recurso. Éste, «previa ponderación, suficientemente razonada, entre el perjuicio que causaría al interés público o a terceros la suspensión y el perjuicio que se causa al recurrente como consecuencia de la eficacia inmediata del acto recurrido» podrá suspender la ejecución del acto impugnado cuando concurran alguna de las siguientes circunstancias: a) Que la ejecución pudiera causar perjuicios de imposible o difícil reparación; b) Que la impugnación se fundamente en alguna de las causas de nulidad de pleno derecho previstas en el artículo 62.1 LRJAP.

Por lo que respecta a la suspensión en vía jurisdiccional, el artículo 130 de la Ley 29/1998, de 13 de julio, reguladora de la Jurisdicción Contencioso-administrativa establece que el juzgador, previa valoración circunstanciada de todos los intereses en conflicto, podrá acordar la medida cautelar únicamente cuando la ejecución del acto o la aplicación de la disposición pudieran hacer perder la finalidad legítima del recurso, denegándose cuando de la medida pudiera seguirse perturbación grave de los intereses generales o de tercero.

59 Artículos 181.3 LCE; 142.3 LCPV.

60 Esta tramitación de urgencia puede tener especial sentido en relación con la ley vasca porque, como su propio supuesto de hecho indica, estamos ante «circunstancias que aconsejen la adopción de medidas urgentes» 
El vencimiento del plazo máximo sin que se hubiese dictado y notificado resolución plantea un panorama algo más complejo, que conviene tratar de forma ordenada:

a) Si el procedimiento ha sido iniciado de oficio, y teniendo en cuenta que estamos ante el ejercicio de una potestad de intervención, se produce la caducidad del mismo (artículo 44.2 LRJAP).

b Los problemas derivan fundamentalmente de los casos en los que dicho procedimiento se ha iniciado a solicitud del interesado. La disparidad de situaciones existentes nos obliga a un tratamiento particularizado de la regulación de cada Comunidad Autónoma:

b.1. Extremadura. El Decreto 98/2001, de 26 de junio arriba citado contempla en el listado obrante en su anexo cada una de las medidas de intervención de manera separada, estableciendo (junto al plazo del procedimiento) el sentido desestimatorio del silencio ${ }^{61}$.

b.2. País Vasco. La ausencia de regulación específica sobre el silencio conlleva la aplicación de la regla general contenida en el artículo 43.2 LRJAP, en virtud de la cual la solicitud debe entenderse estimada, naciendo así una resolución presunta de signo positivo que «tiene a todos los efectos la consideración de acto finalizador del procedimiento» (artículo 44.3 LRJAP) y cuyo sentido no puede ser alterado por la eventual resolución expresa posterior que "sólo podrá dictarse de ser confirmatoria del mismo» (artículo 44.4 a) LRJAP).

b.3. Galicia. De acuerdo con el artículo 2 de la «Ley 6/2001, de 29 de junio, de adecuación de la normativa de la Comunidad Autónoma de Galicia a la Ley 4/1999, de 13 de enero, de modificación de la Ley 30/1992, de 26 de noviembre, de régimen jurídico de las administraciones públicas y del procedimiento administrativo común», «los interesados podrán entender desestimadas sus solicitudes por silencio administrativo en los procedimientos en que así se establece en el anexo de la presente ley si al venci-

61 Curiosamente no se alude a la caducidad, lo que sin duda es una incorrección técnica. 
miento del plazo máximo establecido en cada caso no se ha notificado resolución expresa».

Pues bien, considerando que en el anexo se alude únicamente a "procedimientos relacionados con la inscripción de actos en el registro de cooperativas» (para los que se prevé el silencio negativo), la solución pasaría por ser la misma que la referida en el apartado anterior para el País Vasco (esto es, aplicación de la regla general del silencio positivo).

No obstante, en el caso gallego cabría negar la más mínima virtualidad al silencio administrativo si se interpretara que la falta de mención expresa a la posibilidad de iniciación a petición de parte excluye ésta. Si concluyéramos que la intervención temporal del artículo 140 LCG sólo puede iniciarse de oficio, el vencimiento del plazo máximo para dictar y notificar resolución determinaría la caducidad del procedimiento ${ }^{62}$ tal y como hemos apuntado en el punto a).

b.4. Aragón. Al igual que en Galicia, el Anexo de la «Ley 8/2001, de 31 de mayo, de adaptación de procedimientos a la regulación del silencio administrativo y los plazos de resolución y notificación», no incluye dentro de su listado referencia alguna al procedimiento de intervención temporal, lo que en aplicación del artículo 2 de la misma ley conlleva la estimación de la solicitud por silencio positivo63.

En nuestra opinión la solución del silencio positivo tiene difícil justificación, resultando de todo punto insatisfactoria la estimación presunta de la intervención, máxime si observamos la disparidad que implica comparativamente a la caducidad. Sin restar importancia a los intereses o derechos de los solicitantes, lo cierto es que estamos ante

62 Según hemos comentado en la nota al pie núm. 46, el hecho de que el procedimiento se inicie únicamente de oficio no arrincona a los interesados que podrían formular la pertinente denuncia. En todo caso, es indiscutible que la condición de denunciantes no les coloca en una posición pareja a la que posee el interesado que insta un procedimiento.

63 Artículo 2 de esta Ley 8/2001 señala: «Los interesados podrán entender desestimadas sus solicitudes por silencio administrativo en los procedimientos en que así se prevé en el Anexo de la presente Ley, sin perjuicio de la obligación de la Administración de dictar resolución expresa». 
una medida excepcional que, como se recuerda constantemente, debe apreciarse con particular prudencia.

Por otra parte, el juego del silencio administrativo plantea un problema adicional de igual o mayor envergadura: habida cuenta de que la intervención puede revestir fórmulas distintas de variada intensidad, ¿cuál se supone que es la medida interventora adoptada? ¿acaso la solicitada por quien instó el procedimiento? ¿y si tal concreción no se produjo en la solicitud circunscribiéndose ésta a pedir «el ejercicio de las facultades contempladas» en el precepto de aplicación que en su caso proceda?

Entendemos que una medida de este tipo exige una previsión de silencio desestimatorio que, obviamente, podría ser objeto de impugnación por parte del solicitante interesado en la adopción de la intervención temporal.

\section{Las Medidas de Intervención \\ 1. TipologíA}

Frente al modelo completamente indefinido del Reglamento de $1978^{64}$, la normativa posterior ha tendido invariablemente a tipificar las medidas interventoras concretas que pueden establecerse. Tipicidad que, en cualquier caso, se funda en imperativos de seguridad jurí-

64 Artículo 136 Reglamento 1978: «(...) cuando así lo requieran las circunstancias concurrentes y la trascendencia que revistan los hechos comprobados, podrán adoptarse, previo informe de la Inspección de Trabajo las siguientes medidas:

a) La intervención temporal, al amparo de las funciones estatales que vienen reconocidas en los arts. 52 y 58 de la Ley. (...)

b) Remoción de los titulares de los órganos de gobierno, directivos, fiscalizadores o gerenciales, juntamente o no, con la intervención temporal de la Entidad, que tendrá el mismo carácter y alcance que el señalado en el apartado a) de este número.

(...)».

Esta remisión a los arts. 52 y 58 de la Ley (en referencia a la Ley general de cooperativas de 1974) no aportan mayor concreción al precepto. El artículo 52 Ley 1974 es el alusivo a la asunción por el Estado de «la promoción, estímulo, desarrollo y protección del movimiento cooperativo, y de sus entidades» como tarea de interés social; por su parte, el artículo 58 de la misma ley atribuye al Ministerio de Trabajo las facultades en materia cooperativa.

Hoy en día, esta previsión del Reglamento de 1978 sería, a nuestro juicio, inconstitucional. 
dica y constituye garantía ineludible para la protección de los derechos constitucionales afectados por la intervención.

En relación con este extremo hay cierta coincidencia en las legislaciones recogiéndose básicamente tres medidas de intervención graduadas de menor a mayor intensidad y que pasamos a tratar separadamente empleando la terminología más frecuente entre la doctrina:

\section{a) Intervención-presidencia}

Se basa en el nombramiento de uno o más interventores con facultades de convocar, establecer el orden del día y presidir la Asamblea Genera/65.

Varias son las cuestiones que merecen ser destacadas respecto de esta figura:

a) Las leyes extremeña y gallega utilizan el término "funcionario»; no así las leyes vasca y aragonesa que, en cuanto aluden a «interventores», parecen admitir que el tercero o terceros que ejerciten las facultades previstas en relación con la Asamblea General pueden o no tener la condición de funcionarios públicos. Debe apuntarse que en ningún caso se alude a los Cuerpos de procedencia de tales funcionarios, ni a sus niveles o grados personales ${ }^{66}$.

En todo caso - y esta apreciación sirve igualmente para el resto de medidas- los interventores deberán acomodar su gestión a lo preceptuado en la legislación correspondiente, en este caso la cooperativa. Ello no implica la pérdida de su condición de agentes públicos (sean o no funcionario, los designados como interventores), «ni desvirtúa el dato de que su presencia en la empresa y la suplantación de los órganos ordinarios de la misma producida a su través son una imposición unilateral de la Administración, tramitada y ejecutada conforme a un procedimiento administrativo» ${ }^{67}$.

65 Artículos 96.2 LCA; 181.1 a) LCE; 140.1 a) LCG; 142.1 a) LCPV.

66 La inexistencia de esta mención es lógica por su excesivo detalle. En todo caso, y dada la discrecionalidad de este nombramiento, habría que estar a imperativos de sentido común conforme a los cuales deberá darse una correlación entre la titulación, grado, ... del eventual funcionario designado y las labores propias que como interventor está llamado a desplegar. El mismo criterio se impone caso de que el interventor designado no fuera funcionario público.

67 Gamero Casado, Eduardo, op. cit., pág. 152. 
b) Paz Canalejo ha constatado que "esta medida es, en cierto modo, una duplicidad atípica de la facultad judicial de convocar Asambleas, ordinarias o extraordinarias» ${ }^{68}$ en los supuestos en que aquéllas no fueren convocadas en los plazos indicados para ello69, con la diferencia sustancial de que el Juez debe designar como Presidente a un socio de la cooperativa, cosa que no ocurre en la intervención gubernativa.

Parece claro que en el plano teórico esta duplicidad es factible: la falta de convocatoria de la Asamblea General puede causar perjuicios a los socios y, por lo demás, se tipifica como infracción por las distintas leyes autonómicas ${ }^{70}$ (hecho éste a tener en cuenta en relación con aquellos supuestos de hecho que exigen la comisión de irregularidades). Sin embargo, deben tomarse en consideración dos aspectos:

- La convocatoria judicial que incluye el nombramiento por el Juez del Presidente de la Asamblea no exige ningún requisito adicional al ya comentado de ausencia de convocatoria conforme al cauce y plazos establecidos, bien entendido que estamos ante un mecanismo regido por el principio de rogación. Por el contrario, la intervención gubernativa requiere la existencia de un interés público que va, por tanto, más allá de la mera falta reseñada. Así las cosas, la no convocatoria de la Asamblea General permite en todo caso la solicitud de la misma al órgano jurisdiccional competente, pero no siempre constituye presupuesto habilitante para la intervención temporal.

- La aplicación de esta intervención-sustitución, en cuanto instrumento excepcional, debe estar presidida por el principio de proporcionalidad lo que, a nuestro juicio, excluye la posibilidad de apreciar la convocatoria judicial y esta modalidad de intervención temporal como mecanismos alternativos y el riesgo consiguiente de una eventual simultaneidad. Desde este premisa, creemos que la intervención administrativa ha de tener un carácter subsidiario respecto de la judicial y siempre, por supuesto, que exista un interés público que la justifique.

68 Paz Canalejo, en VVAa (dir. Sánchez Calero, Fernando y Albaladejo, Manuel), Comentarios al Código de Comercio,... op. cit., pág. 904.

69 Artículos 29 LCA; 31 LCE; 33 LCG; 33 LCPV.

70 Artículos 94.5 e) LCA; 173 a) LCE; 139.2 .2 b); 139.5 LCPV. 


\section{b) Intervención-aprobación}

Consiste en la intervención de los órganos de la cooperativa, cuyos actos sólo serán válidos en la medida en que cuenten con la aprobación de los interventores ${ }^{71}$. Nos encontramos, pues, ante algo más que un poder de veto puesto que se condiciona la validez de los actos de los órganos sociales a la aprobación expresa de los interventores; no en vano algunos de los artículos especifican que la ausencia de esta aprobación expresa determina la nulidad de los acuerdos adoptados.

Junto a esta modalidad, la norma gallega introduce un tipo que, aunque pudiera asemejarse a éste, es de menor intensidad por cuanto se prevé la designación bien de un funcionario, bien de un representante del Consejo Gallego de Cooperativas con funciones de asesoramiento de los órganos sociales de la cooperativa, a cuyas reuniones asistirá pero sin que la validez de los acuerdos adoptados por éstos se condicione a su aprobación y sin que, por otra parte, se deduzca poder de veto alguno en su favor (artículo 140.2 LCA).

En todo caso, ¿qué se comprende en la mención «órganos de la cooperativa»? La literalidad de los artículos que nos ocupan conduce a situaciones disímiles, a saber:

- Alguna de las regulaciones parecen excluir esta técnica de intervención-aprobación en relación con los acuerdos de la Asamblea General: así ocurre en el caso aragonés cuando, tras la mención de la intervención-presidencia, se alude al control del funcionamiento «del resto de los órganos sociales de la cooperativa, cuyos acuerdos serán nulos sin su aprobación». Parecida línea sigue la LCE, que establece la necesidad de aprobación por los interventores de «los acuerdos adoptados y las decisiones tomadas por los órganos rectores de la cooperativa», fórmula copiada de la LGC de 1987.

La incógnita en este caso se centra en si tales menciones incluyen únicamente los actos del Consejo Rector o se extienden también a las decisiones del llamado Gerente. Desde nuestro punto de vista, han de entenderse concernidos ambos, si bien la mayor importancia de los primeros (acuerdos del Consejo

71 Artículos 96.2 LCA; 181.1 b) LCE; 140.1 b) LCG; 142.1 b) LCPV. Al igual que en el primer apartado, las normativas gallega y extremeña aluden a «funcionarios». 
Rector) está fuera de toda duda y, de hecho, son éstos los que comprometen auténticamente el gobierno y la gestión de la sociedad cooperativa.

- A diferencia de las anteriores, las leyes vasca y gallega realizan una referencia omnicomprensiva a "órganos de la cooperativa», que no permitiría entender fuera de ella al órgano asambleario $^{72}$.

\section{c) Intervención-sustitución}

Constituye la medida más intensa por cuanto implica la suspensión temporal de los administradores de la cooperativa, con nombramiento de uno o más administradores provisionales ${ }^{73}$.

Es esencial poner de relieve que esta clase de intervención sólo es posible en relación con los órganos ordinarios de administración de la cooperativa, de manera que cualquier intento de sustitución de la Asamblea General carece de cobertura constitucional74 y constituiría de facto en una expropiación temporal por afectar a la titularidad de la empresa.

Este es el sentido con el creemos debe interpretarse la ambigüedad de la previsión extremeña de «suspensión temporal de la actuación de los órganos sociales de la cooperativa», locución que podría plantear dudas sobre los órganos a los que se extiende. La ley vasca ha sido más cuidadosa al evitar este tipo de alusión genérica, especificando que la sustitución puede obrar respecto de los «administradores».

72 Gamero manifiesta que, aun cuando la afectación a los acuerdos de la asamblea puede hacer que la medida se vea excesivamente intensa, «la previsión parece lógica, por cuanto los órganos asamblearios podrían adoptar igualmente acuerdos contrarios al interés público presente en la empresa», haciendo insuficiente la intervención circunscrita a los órganos rectores. GAMERO CASADO, Eduardo, op. cit., pág. 182.

73 Artículos 181.1 c) LCE; 142.1 c) LCPV. Esta medida no está prevista en la LCA, ni en la LCG.

74 Gamero Casado, Eduardo, op. cit., págs. 183-184. El desgraciado y célebre caso de la intervención de "PSV, Promoción Social de Viviendas» acordada por el Consejo de Ministros el 11 de febrero de 1994 y prorrogada por acuerdos de 20 de enero de 1995 y de 15 de septiembre del mismo año, parece desdecir esta afirmación. No obstante, hemos de reseñar que, en este caso, la intervención ha estado en la práctica bajo permanente mandato de la autoridad judicial y no puede considerarse un auténtico ejemplo de intervención gubernativa en sentido estricto. 
En cualquier caso, el órgano social al que primariamente se dirige esta medida es el Consejo Rector en su calidad de encargado del gobierno, gestión y representación de la sociedad cooperativa ${ }^{75}$, pudiéndose plantear más dudas en relación con el denominado Gerente (artículo 39 LCE), de existencia no necesaria, y con facultades limitadas al tráfico empresarial ordinario.

\section{Naturaleza jurídica de la intervención temporal}

Hemos reseñado con anterioridad que tanto los presupuestos habilitantes de la intervención como las medidas concretas en que ésta pudiere consistir dan muestra de que nos encontramos ante una actuación pública de carácter excepcional, cuya naturaleza jurídica no siempre presenta perfiles nítidos.

Tradicionalmente las previsiones normativas han venido ligando la intervención temporal a la función inspectora y al ejercicio de la potestad sancionadora en materia cooperativa ${ }^{76}$. Una amalgama que llevaba al punto de convertir aquélla en una medida puramente accesoria a las facultades públicas mencionadas.

Así ocurría en el Reglamento de 1971 que configuró la intervención como una «medida preventiva o de seguridad» limitada a la esfera de la función inspectora y que, aunque actuaba sin perjuicio de la resolución definitiva derivada del expediente sancionador (artículo 93 Reglamento 1971), poseía una clara conexión con éste adquiriendo tintes de auténtica medida cautelar.

El Reglamento de 1978 plantea otro tipo de dificultades: por un lado, su dicción literal parecía subrayar la independencia de la intervención respecto del expediente sancionador ${ }^{77}$. No obstante, lo cierto es que se incluía en el artículo 136 que, bajo el engañoso rótulo de

75 Asimismo, incluimos aquí el supuesto de administrador único que prevé la LCPV para aquellas sociedades cooperativas con un número no superior a diez socios (artículo 41.1 LCPV)

76 Hernando Delgado destaca la intervención de cooperativas «como medida complementaria de las resoluciones sancionadoras». Hernando Delgado, Justo, op. cit., pág. 723.

77 El artículo 136.1 a) del mencionado reglamento contemplaba la intervención temporal «sin perjuicio de la resolución definitiva que se dicte en el expediente sancionador cuando procediese la incoación de éste», de lo que cabe derivar que podía acordarse la intervención aun en el supuesto en que no se hubiesen cometido infracciones que justificasen la apertura del mencionado expediente. 
«Otras medidas aplicables», venía a enumerar una suerte de actuaciones que, en esencia, constituían sanciones máximas ${ }^{78}$.

La LCPV actualmente vigente mantiene en buena medida esta relación entre el régimen sancionador y la intervención temporal, aunque se trate de remarcar la autonomía de $\operatorname{ambos}^{79}$. Ciertamente la intervención temporal puede acordarse con independencia de un eventual procedimiento sancionador pero, como hemos visto, el supuesto de hecho parte de la existencia de actuaciones irregulares por parte de la entidad cooperativa. Sin ánimo de anticipar la virtualidad que en la práctica pueda tener el art 142 LCPV, debemos decir que se nos antoja poco realista la posibilidad de que una «actuación irregular» no constitutiva de algunas de las infracciones legalmente previstas, pueda lesionar gravemente los intereses de los socios o de terceros dando así lugar a la adopción de las «medidas urgentes» en que consiste la intervención.

A nuestro juicio, puede afirmarse que toda intervención temporal encierra notas de medida preventiva: de un lado, la intervención como tal ni constituye ni puede constituir un fin en sí misma, sino que se halla configurada como un instrumento dirigido a la evitación de riesgos para una serie de intereses o, caso de que tales riesgos se hayan materializado de algún modo, tendente a eludir males mayores; $y$, por otra parte, su propia limitación en el tiempo le dota igualmente de ese carácter provisional.

Todo ello, sin embargo, no puede llevarnos a concluir que estamos ante una medida cautelar en sentido técnico, ya que la intervención temporal carece de un rasgo típico de aquélla: nos referimos a su carácter accesorio en relación con otro procedimiento, el entendido como principal y a cuya efectividad se dirige ${ }^{80}$.

78 El apartado b) del artículo 136.1 Reglamento 1978 contemplaba la «remoción de los titulares de los órganos de gobierno, directivos, fiscalizadores o gerenciales, juntamente o no, con la intervención temporal de la Entidad», medida que conforme al 136.3 competía al Consejo de Ministros; y el c) del mismo artículo, la «disolución de la Entidad por descalificación».

79 Artículo 142.4 LCPV: «La intervención temporal regulada en este artículo se podrá producir con ocasión de la incoación de expediente sancionador o con independencia del mismo».

80 Un supuesto singular es el contemplado en el artículo 166.2 a) de la Ley 2/1999, de 31 de marzo, de Sociedades Cooperativas Andaluzas (BOE 107/1999, de 5 de mayo; BOJA 46/1999, de 20 de abril) que prevé la designación de «una o más personas con la facultad de convocar la Asamblea General, establecer el orden del día de la 
Dicho esto, compartimos la tesis de GAMERo para quien estamos ante una potestad administrativa, "clasificable entre las técnicas de intervención administrativa en la economía» y que, por su carácter instrumental, no constituye un fin en sí misma, sino que se trata de una medida al servicio de la actuación administrativa proyectada a la consecución de variados fines ${ }^{81}$.

\section{Los derechos constitucionales afectados. Consecuencias en los principios de aplicación}

\section{A. Los derechos constitucionales afectados por la intervención}

\section{APUNTES PRELIMINARES}

Una primera aproximación a los derechos constitucionales que pudieren resultar afectados por la intervención temporal apunta a dos de ellos de forma destacada: el derecho a la propiedad privada y el derecho a la libertad de empresa.

Sin embargo, el análisis posterior permite advertir que esta primera impresión requiere ser puntualizada:

a) Es unánime la opinión que sitúa como derecho principalmente afectado el derecho a la libertad de empresa. En el siguiente apartado tendremos ocasión de tratar el modo en que se produce esta implicación y su alcance.

b) Plantea más dificultades el derecho a la propiedad privada amparado en el artículo 33.1 CE ${ }^{82}$. HeRnANDo apunta a que la in-

misma y presidirla» como «medida de carácter provisional» que el órgano competente para resolver puede acordar en el seno de un procedimiento sancionador. Adviértase que, pese a la coincidencia con la medida que hemos denominado «intervención-presidencia», la ley andaluza configura aquí una auténtica medida cautelar.

81 Gamero CASAdo, Eduardo, op. cit., págs. 236-240.

82 Buena parte de la confusión en torno a si la intervención actúa o no sobre el derecho de propiedad, responde a cierta tendencia doctrinal a emparejar ambos derechos. Así, cuando se afirma que «el derecho de propiedad constituye el soporte de la libertad de empresa» (ENTRENA CUESTA), «ese derecho a la empresa está basado justamente en la propiedad», "sobre la propiedad y libertad se funda la empresa» (ambas de ARIÑO ORTIZ). Por orden de citas, ENTRENA CUESTA, Rafael, «El modelo económico de la Constitución Española de 1978», en VVAA, La empresa en la Constitución española, Aranzadi, Pamplona, 1989, pág. 31; ARIÑO ORTIZ, Gaspar, «Constitución, modelo económico y nacionalizaciones», Revista de Derecho Bancario y Bursátil, núm. 9, año III, 
tervención puede ser un primer paso hacia el despojo de la titularidad de la empresa a través de la expropiación forzosa ${ }^{83}$, opinión que, ciertamente, no puede ser rebatida. Sin embargo, el hecho de que la intervención se constituya en un hipotético estadio intermedio previo a la expropiación, no convierte este mecanismo en lo que no es. Según hemos referido en líneas precedentes, la intervención temporal supone una publificación de la gestión, a veces muy intensa, pero en principio ninguna de las medidas afectan a la titularidad de la empresa que permanece inalterada con todas las consecuencias que de ello deriven.

\section{Intervención temporal y derecho a la libertad de empresa}

El derecho a la libertad de empresa es un derecho constitucionalmente reconocido - artículo $38 \mathrm{CE}$ - del que se afirma un doble plano ${ }^{84}$ : a) En su vertiente institucional, el derecho a la libertad de empresa actúa como garantía para el mantenimiento de la economía de mercado, de modo que los poderes públicos se ven comprometidos a asegurar las reglas de la libre competencia y a someterse a ellas en lo atinente a la actividad económica desarrollada por el sector público; b) En su vertiente subjetiva, permite al titular del derecho reaccionar frente a cualquier medida restrictiva, excluyente o que resulte desproporcionada para la consecución del fin de interés general que justifique aquélla85.

enero-marzo 1983, pág 24; del mismo autor, "Propiedad, libertad y empresa», en WAA, La empresa en... op. cit., pág. 109.

83 Hernando Delgado, Justo, op. cit., págs. 716 y 717.

84 Muñoz MAChADO, Santiago y BAÑo LeÓn, José María, "Libertad de empresa y unidad de mercado», en VVAA, La empresa en... op. cit., págs. 214-220.

85 En contraposición a las opiniones que dan preeminencia al aspecto institucional, MARTín-Retortillo argumenta que «el modelo se apoya, básicamente, en la sanción de la libertad de empresa como auténtico derecho (...) cuyo titular ostenta un status jurídicamente protegible por los Tribunales de Justicia». Martín-Retortillo Baquer, Sebastián, Derecho Administrativo Económico I, La Ley, Madrid, 1988, pág. 86.

Merece destacarse que esta vertiente individual se formula prioritariamente de un modo negativo de manera que «lo decisivo no sería la protección del derecho subjetivo del empresario a desarrollar autónomamente su actividad en el sistema económico, sino la posibilidad de rechazar las inmisiones de los poderes públicos en el sistema de mercado regulado autónomamente (...) cuando no estuvieran justificados por la protección de otros intereses constitucionalmente protegidos». Duque Domínguez, Justino F., «Constitución económica y Derecho Mercantil», en WVAA, Jornadas sobre la reforma de la legislación mercantil, Civitas/Fundación Universidad-Empresa, Madrid, 1979, pág. 97. 
Estamos, en cualquier caso, ante un derecho que, como los demás, no es incondicionado o absoluto, sino que se ve sometido a las limitaciones que, en virtud del 53.1 CE, puedan establecer por ley; «ley que en todo caso deberá respetar su contenido esencial».

¿En qué se concreta la referencia del artículo 53.1 CE? El carácter bidireccional del derecho, unido a la primacía que el TC otorga al 38 CE como garantía institucional86, convierte la determinación de ese «contenido esencial» en tarea que algunos han considerado «imposible» 87.

Rojo ha tratado de definir los contornos del mismo distinguiendo en él tres aspectos ${ }^{88}$ : libertad de acceso al mercado, libertad de ejercicio o permanencia en el mercado y libertad de cesación o de salida del mismo.

86 Predominio que, según el TC, «es patente» [FJ Tercero, STC 83/1984, de 24 de julio; rec. 80/1983; Ponente: Rubio Llorente, Francisco; BOE 203/1984, de 24 de agosto; EDJ 1984/83].

87 Sánchez-Bella Carswell, Alfredo, "El principio de libertad de empresa», en VVAA, La Constitución Española. Lecturas para después de una década, Editorial de la Universidad Complutense/Fundación para la Libertad y la Democracia, Madrid, 1989, pág. 220; Martín-Retortillo Baquer, Sebastián, op. cit., pág. 85.

El propio TC, reconociendo que ésta es una «cuestión que no está exenta de graves dificultades de definición a priori con carácter abstracto y de general aplicación» [FJ Quinto, STC 37/1987, de 26 de marzo; rec. 685/1984; Ponente: Leguina Villa, Jesús; BOE 89/1987 de 14 de abril; EDJ 1987/37], ha evitado durante mucho tiempo pronunciarse sobre la misma, actitud que ha merecido severas críticas doctrinales. Véase. ArIÑO ORTIZ, Gaspar, Principios constitucionales de la libertad de empresa. Libertad de comercio e intervencionismo administrativo, Marcial Pons/ldelco, Madrid, 1995, pág. 84.

Por su parte De JUAN AsENJo pone de relieve que no debería hablarse de libertad de empresa «in genere», puesto que «en cada área de la economía la libertad del empresario se mueve dentro de un marco más o menos amplio y sometido a unos condicionamientos más o menos exigentes». Desde este planteamiento, la libertad de empresa como derecho subjetivo «queda a salvo siempre que el empresario permanezca libre de introducirse en ese sector o abandonarlo». De JuAn Asenjo, Oscar, La Constitución económica española. Iniciativa económica pública «versus» iniciativa económica privada en la Constitución española de 1978, Centro de Estudios Constitucionales, Madrid, 1984, pág. 161.

88 Roso, Angel, «Actividad económica pública ..., op. cit., págs. 327-335. Esta formulación ha sido, posiblemente, la que más éxito ha cosechado entre la doctrina y es seguida, entre otros, por DE GISPERT PASTOR, María Teresa, "La noción de empresa en la Constitución española», en VVAA, La empresa en ..., op. cit., págs. 43-46; CosCULlUELA MonTANER, Luis, «Reflexiones sobre los presupuestos constitucionales y de Derecho Comunitario Europeo y los principios generales del Derecho Público Económico», en WVAA (coord.. Cosculluela Montaner, Luis), Estudios de Derecho público económico. Libro Homenaje al Profesor Dr. D. Sebastián Martín-Retortillo, Civitas/Endesa/lbercaja, Madrid, 2003, pág. 128; ARIÑo ORTIZ, Gaspar, Principios constitucionales ..., op. cit., págs. 85-92 y 132 (este último sigue la propuesta de Roso, aunque sintetizada de un modo algo distinto). 
Partiendo de esta delimitación, no existe sin embargo acuerdo doctrinal sobre el modo en que incide la intervención administrativa en este derecho a la libertad empresarial. DE JUAN la contempla como excepción al contenido esencial, una suerte de ataque frontal al derecho que sólo encuentra amparo constitucional por estar expresamente previsto en el texto fundamenta|89. GAMERO, por el contrario, sitúa este mecanismo en las fronteras externas del derecho, conceptuándolo más como limitación y sin que, por tanto, suponga incidencia alguna en el contenido esencial del mismo ${ }^{90}$.

Sea cual sea la postura mantenida, e incluso otras que se colocan entre ambos extremos ${ }^{91}$, lo cierto es que nadie pone en duda que la intervención implica una merma -temporal, extraordinaria y legítima si se atiene a los límites legalmente establecidos- del derecho reconocido en el artículo 38 CE, sólo justificable por razones de interés público.

\section{B. Los principios en la adopción y aplicación de la intervención temporal}

\section{EL PRINCIPIO DE PROPORCIONALIDAD}

El principio de proporcionalidad, que se define como la adecuación o correspondencia entre los fines perseguidos y los medios empleados para alcanzar estos fines, constituye una exigencia primaria en el ejercicio de actividades administrativas de naturaleza ablatoria. Un principio al que acompaña y complementa otro, no menos importante: el favor libertatis o pro libertate ${ }^{92}$, conforme al cual «cuando la norma que establece la potestad de intervención puede razonablemente optar entre varias medidas alternativas para conseguir su finalidad ordenadora, debe necesariamente elegir entre la que resulte me-

89 De Juan Asenjo, Oscar, op. cit., págs. 161-162.

90 GAMERO CASADO, Eduardo, op. cit., págs. 102-108.

91 Hernando Delgado, Justo, op. cit., pág. 717. Ariño Ortiz, Gaspar, «Constitución, modelo económico ..., op. cit., págs. 17-18 y 20-21.

92 GARCíA DE ENTERRÍA en una elocuente frase recuerda que «la proporcionalidad que debe existir siempre entre la limitación de la libertad y los fines que en cada caso se persiguen y la obligada valoración pro libertate constituyen hoy dos tests de cuya superación depende la constitucionalidad misma de las normas y, por supuesto, la de su concreta aplicación por la Administración». García de EnTERRÍA, Eduardo y FERnÁndez RoDRíguez, Tomás Ramón, Curso de Derecho Administrativo, vol. II, Civitas, Madrid, 1993, 4. ${ }^{a}$ edición, pág. 118. 
nos restrictiva de la libertad de los sujetos sobre los que vaya a ser empleada» ${ }^{93}$.

La aplicación práctica de ambos principios en la intervención temporal94 parece evidente y debe desencadenarse en dos momentos distintos: primero, al adoptar la decisión administrativa, en cuanto si la satisfacción del interés público puede obtenerse mediante el empleo de técnicas menos extremas, han de anteponerse éstas a la intervención ${ }^{95}$; y en segundo término, supuesto que la resolución optara por esta medida interventora como la más idónea para la situación existente, los principios referidos deben presidir la elección de la medida concreta a poner en práctica, eligiendo la más adecuada y proporcional a la gravedad de la situación. En este punto, no debe olvidarse que las medidas son de intensidad variable y la preferencia por una $u$ otra determina una mayor o menor restricción de los derechos afectados.

\section{El carácter temporal y su indefinición}

Si atendemos a que la «transitoriedad $»^{96}$ se predica como característica propia y consustancial a una intervención que se adjetiva de «temporal», resulta ciertamente insólito que las regulaciones silencien un extremo que debería considerarse esencia| ${ }^{97}$ : nos referimos a la duración de las medidas de intervención.

La respuesta inmediata y lógica a esta incógnita pasa por admitir que la «temporalidad» se extiende a la duración del presupuesto habilitante, esto es, la intervención perdurará en tanto en cuanto no desaparezcan las causas que motivaron la adopción de la medida ${ }^{98}$. A

93 SAntamaría PAStor, Juan Alfonso, op. cit., vol. II, pág. 262

94 Sobre el principio de proporcionalidad aplicado a la intervención de empresas, Gamero CASADO, Eduardo, op. cit., págs. 254-259.

95 La excepcionalidad de este mecanismo es apuntada comúnmente como una de sus características. BAssols Coma, Martín, op. cit., pág. 203; GAMERo CASAdo, Eduardo, op. cit., págs. 153-154.

96 GADEA SOlER, Enrique, op. cit., pág. 332

97 GAMERO recuerda que la falta de establecimiento del elemento temporal es común a las regulaciones sectoriales que disciplinan la intervención de empresas, a lo que se une «que no existen principios generales del Derecho de cuya aplicación derive la temporalidad de la intervención de empresas, ni tampoco la jurisprudencia ha sentado precedentes en este sentido». Sobre los argumentos en que se apoya este autor para afirmar la temporalidad, véase págs. 156-160 de su obra citada.

98 GADEA Soler, Enrique, op. cit., pág. 332. 
nuestro juicio, esta reflexión — que estaría avalada por el vacío que deja la regulación - no puede aceptarse sin matices.

Es innegable que la determinación «ex lege» de la duración de cualquiera de las medidas de intervención presenta dificultades muy serias no sólo por la imposibilidad de aventurar la infinidad de circunstancias concurrentes en cada supuesto, sino porque una excesiva rigidez pondría en peligro la eficacia de la propia medida.

Sin embargo, este planteamiento olvida que la intervención temporal constituye una ablación del derecho a la libertad de empresa que, aunque legítima, no puede perpetuarse so pena de afectar al contenido esencial del mismo ${ }^{99}$. En este sentido, la suspensión que la intervención implica de ciertas facultades del derecho, sobrevendría insostenible de no establecerse un límite temporal máximo, a partir del cual la Administración Pública debe levantar la intervención abriendo la puerta, en su caso, a soluciones de muy distinto cariz ${ }^{100}$.

Por lo demás, no debe confundirse la «temporalidad», que va ligada a las medidas, con la «urgencia», como parte del presupuesto habilitante. En este punto, y aunque la intervención ha ido frecuentemente asociada a la premura en la necesidad de dar una respuesta pública ante determinadas situaciones, sólo la ley vasca muestra expresamente ese carácter urgente del mecanismo, lo que, sin duda, restringe aún más su campo de acción ${ }^{101}$.

\section{Conclusiones}

La intervención temporal de sociedades cooperativas constituye una potestad administrativa que habilita para el ejercicio de una serie

99 De Juan Asenjo, Oscar, op. cit., págs. 162-163; Paz Canalejo, en VVAA (dir. SánChez Calero, Fernando y Albaladejo, Manuel), Comentarios al Código de Comercio,... op. cit. , págs. 909-910.

100 Suelen apuntarse las siguientes posibilidades: a) Devolución de la empresa a sus gestores ordinarios; b) Asunción por el Estado de la titularidad de la empresa, procediendo a su expropiación, bien para nacionalizarla, bien para su enajenación a terceros; c) Liquidación de la empresa.

ArIÑo ORTIZ, Gaspar, «Propiedad, libertad ..., op. cit., pág. 123; Gamero CASAdo, Eduardo, op. cit., pág. 161.

101 Esta nota de urgencia se recogía también en la LCCV de 1985 y fue mantenida en su reforma de 1995. 
de mecanismos de injerencia pública de carácter excepcional que encuentra su engarce constitucional en el artículo 128.2 CE.

La circunstancia de su previsión en la norma fundamental no elimina su naturaleza extraordinaria que conlleva unas especiales cautelas en cuanto a su puesta en práctica y que requiere, en todo caso, una ley previa habilitante - general o singular, con las matizaciones señaladas en este trabajo- y la aplicación de los principios a los que obliga la moderación en la actividad administrativa limitativa.

Entendiendo por tanto legítima la contemplación de la intervención temporal en diversas leyes autonómicas sobre cooperativas, nuestro análisis ha tratado de dilucidar los problemas que la regulación contenida en las mismas presenta y que, en síntesis, son los siguientes:

En primer lugar, y aún atendiendo a que, en su condición de mecanismo público de intervención, esta figura debe ir dirigida a la satisfacción de intereses generales, tal vez sería exigible una mayor concreción de los presupuestos de hecho habilitantes de la misma. Cierto es que una especificación en detalle es inviable, pero creemos que los supuestos se definen de un modo excesivamente abierto y están plagados de conceptos jurídicos indeterminados que pueden complicar su verificación en la práctica.

Desde nuestro punto de vista este hecho, unido al carácter discrecional de la potestad, tiene consecuencias relevantes por cuanto dificultan el control judicial posterior que, como tal, es indispensable como garantía de legalidad de la actividad administrativa y, sobre todo, en la medida en que el poder judicial se erige en tutelador máximo de los derechos e intereses de los sujetos privados ${ }^{102}$.

En relación con las medidas, habría que establecer un límite temporal máximo en consonancia con una intervención que, aunque adjetivada de temporal, omite cualquier referencia concreta a dicho elemento. Por otra parte, convendría evitar las expresiones ambiguas que

102 Recurriendo a las palabras siempre lúcidas de BAENA DEL ALCÁZAR, conviene no olvidar que «el papel del Derecho administrativo en la economía es actualmente asegurar la libertad del ciudadano contra la intervención invasora, pero cada vez más necesaria, de la Administración en la vida económica, sobre el terreno de los hechos concretos, arbitrando los controles necesarios para dotar a los individuos de garantías jurídicas». BAENA Del AlCÁZAR, Mariano, «El papel del Derecho Administrativo en la Economía», Documentación Administrativa, núm. 94, octubre 1965, pág. 54. 
suscitan dudas sobre el alcance de las propias medidas $y$, fundamentalmente, incertidumbre sobre cuáles son los órganos sociales que podrían resultar afectados por la intervención.

Se requeriría, además, una regulación procedimental mucho más completa de la que presenta la legislación sectorial vigente (a colmar, en su caso, mediante reglamentos de desarrollo, instrumento habitual para concretar cuestiones de procedimiento). En este sentido, y aún cuando la aplicación de la normativa supletoria puede cubrir ciertas carencias, lo cierto es que, al tiempo, plantea soluciones de difícil encaje y, sobre todo, deriva en situaciones en las que los derechos afectados pueden verse seriamente mermados en sus garantías.

Desde esta perspectiva, la necesidad de una regulación idónea del procedimiento no se enfoca tanto a hacer más sencilla y eficaz la propia actuación administrativa, como a la protección de la esfera jurídica de los sujetos implicados.

En síntesis, creemos preciso reforzar la vertiente garantista en relación con los distintos extremos expuestos. Una necesidad que pone en evidencia lo atinado de las afirmaciones vertidas por DUQUE poco después de la entrada en vigor de la Constitución española en relación con el derecho a la libertad de empresa:

«(...) en tesis general, ha variado la naturaleza jurídica y ha dejado de ser una facultad para exigir a los poderes públicos el establecimiento de las condiciones que hicieron posible el ejercicio actual de ese derecho y se ha convertido en la facultad de exigir un ámbito de actuación exenta de la injerencia estatal ...»103.

\section{Bibliografía}

ARIÑo ORTIZ, Gaspar, «Constitución, modelo económico y nacionalizaciones», Revista de Derecho Bancario y Bursátil, núm. 9, año III, enero-marzo 1983, págs. 11-40.

ARIÑO ORTIZ,Gaspar, "Propiedad, libertad y empresa», en VVAA, La empresa en la Constitución española, Aranzadi, Pamplona, 1989, págs. 103-135.

ARIÑO OrTIZ, Gaspar, Principios constitucionales de la libertad de empresa. Libertad de comercio e intervencionismo administrativo, Marcial Pons/ IdelCo, Madrid, 1995.

103 Duque Domínguez, Justino F., op. cit., pág. 94. 
Baena del Alcázar, Mariano, «El papel del Derecho Administrativo en la Economía», Documentación Administrativa, núm. 94, octubre 1965, págs. 4354.

Bassols Coma, Martín, Constitución y sistema económico, Tecnos, Madrid, 1985.

Cosculluela Montaner, Luis, «Reflexiones sobre los presupuestos constitucionales y de Derecho Comunitario Europeo y los principios generales del Derecho Público Económico», en VVAA (coord. Cosculluela Montaner, Luis), Estudios de Derecho público económico. Libro Homenaje al Profesor Dr. D. Sebastián Martín-Retortillo, Civitas/Endesa/lbercaja, Madrid, 2003, págs. 109-138.

De GISPERT PASTOR, María Teresa, «La noción de empresa en la Constitución española», en VVAA, La empresa en la Constitución española, Aranzadi, Pamplona, 1989, págs. 37-102.

De Juan Asenjo, Oscar, La Constitución económica española. Iniciativa económica pública «versus» iniciativa económica privada en la Constitución española de 1978, Centro de Estudios Constitucionales, Madrid, 1984.

Divar GarteizaurrecoA, Javier, Régimen jurídico de las Sociedades Cooperativas, Universidad de Deusto, Bilbao, 1987.

Duque Domínguez, Justino F., "Constitución económica y Derecho Mercantil», en VVAA, Jornadas sobre la reforma de la legislación mercantil, Civitas/ Fundación Universidad-Empresa, Madrid, 1979, págs. 61-129.

ENTRENA CUESTA, Rafael, «El modelo económico de la Constitución Española de 1978», en VVAA, La empresa en la Constitución española, Aranzadi, Pamplona, 1989, págs. 11-36.

GadeA Soler, Enrique, Derecho de las cooperativas. Análisis de la Ley 4/1993, de 24 de junio, de cooperativas del País Vasco, Universidad de Deusto, Bilbao, 1999.

Gamero CASAdo, Eduardo, La intervención de empresas. Régimen jurídico-administrativo, Marcial Pons, Madrid, 1996.

García Echevarría, Santiago, «El orden económico en la Constitución», Libre Empresa, año II, núm. 8, septiembre-octubre 1978, págs. 7-59.

García de Enterría, Eduardo y Fernández Rodríguez, Tomás Ramón, Curso de Derecho Administrativo, vol. II, Civitas, Madrid, 1993, 4. a edición.

HeRNANDO DelGADO, Justo, "La intervención pública de empresas privadas», en VVAA, Homenaje a José Antonio García-Trevijano Fos, Colegio Universitario de Estudios Financieros/Instituto de Estudios de Administración Local, Madrid, 1982, págs. 710-744.

LÓPEZ RoDó, Laureano, «El modelo económico de la Constitución», en VVAA, Administración y Constitución. Estudios en homenaje al profesor Mesa Moles, Servicio Central de Publicaciones de la Presidencia del Gobierno, Madrid, 1981, págs. 441-454.

Martín-Retortillo Baquer, Sebastián, Derecho Administrativo Económico I, La Ley, Madrid, 1988. 
Muñoz MACHAdo, Santiago y BAÑo León, José María, "Libertad de empresa y unidad de mercado», en VVAA, La empresa en la Constitución española, Aranzadi, Pamplona, 1989, págs. 211-232.

OJedA MARín, Alfonso, "La intervención de empresas en el ordenamiento vigente (Sobre la incautación de Hytasa y su constitucionalidad)», Revista Española de Derecho Administrativo, núm. 57, enero-marzo 1988, págs. 73-78.

Polo, Antonio, «El nuevo Derecho de la economía. Su aparición, concepto y relaciones con el Derecho Mercantil», Revista de Derecho Mercantil, vol. I, núm. 3, mayo-junio 1946, págs. 373-413.

Rojo Fernández-Río, Angel, "Actividad económica pública y actividad económica privada en la Constitución Española», Revista de Derecho Mercantil, núm. 169/170, julio-diciembre 1983, págs. 309-341.

Rojo FERnández-Río, Ángel, «El Derecho económico como categoría sistemática», en VVAA, Estudios de Derecho Mercantil en homenaje al profesor Antonio Polo, Editorial Revista de Derecho Privado/Edersa, Madrid, 1981, págs. 977-1014.

SánChez-Bella CARSWelL, Alfredo, «El principio de libertad de empresa», en VVAA, La Constitución Española. Lecturas para después de una década, Editorial de la Universidad Complutense/Fundación para la Libertad y la Democracia, Madrid, 1989, págs. 215-229.

Santamaría PAstor, Juan Alfonso, Principios de Derecho Administrativo, Centro de Estudios Ramón Areces, Madrid, 2002, 4. ㄹ ed., 2 volúmenes.

VVAA (dir. Paz Canalejo, Narciso), Glosa a la Ley de Cooperativas de Euskadi, Consejo Superior de Cooperativas de Euskadi, Vitoria-Gasteiz, 1999.

VVAA (dir. Sánchez Calero, Fernando y Albaladejo, Manuel), Comentarios al Código de Comercio y Legislación mercantil especial, Tomo XX, vol. 3, Editorial Revista de Derecho Privado/Edersa, Madrid, 1994. 